\title{
THE ORIGIN OF MANTLE PERIDOTITES: CRUSTAL SIGNATURES FROM YAKUTIAN KIMBERLITES
}

\author{
Lawrence A. Taylor ${ }^{1}$, Zdslav V. Spetsius ${ }^{2}$, Rene Wiesli ${ }^{1,3}$, Mahesh Anand $^{1}$, Prinya Promprated ${ }^{1}$, \\ and John W. Valley ${ }^{3}$ \\ ${ }^{1}$ Planetary Geosciences Institute, Dept. of Geological Sciences, Univ. of Tennessee, USA; ${ }^{2}$ ALROSA Company, Ltd., \\ Russia; ${ }^{3}$ Dept. of Geology \& Geophyics, Univ. of Wisconsin, USA.
}

\section{INTRODUCTION}

Originally, diamonds were thought to be genetically connected to the kimberlites in which they were found. However, for the last 30 years or so, it has been generally agreed that virtually all diamonds, although found in the kimberlite [and lamproite], had peridotites and eclogites as their original hosts in the mantle (Sobolev, 1977; Meyer, 1987). Moreover, since the mid-80s, our understanding of the tectonic role of subduction has been refined, such that it is now accepted that many mantle eclogites, including diamondiferous ones, had their protoliths in ancient oceanic crust. The history of the thought processes and data bases that went into this drastic change in mantle eclogite genesis is reviewed in this paper, as it provides insight into the scientific method of deduction that occurred. The lessons learned from these studies are revived and applied to the investigation of yet another radical departure from the accepted - i.e., hat some diamondiferous peridotites may have had a similar heritage to the subducted eclogites.

\section{ORIGIN OF MANTLE ECLOGITES}

It is now generally agreed that "mantle" eclogites from kimberlites had their origin in the subduction of oceanic crust beneath the major cratons of the world (e.g., MacGregor and Manton, 1986; Shervais et al., 1988; Kesson and Ringwood, 1989; Taylor and Neal, 1989; Taylor, 1993; Jacob et al., 1994). One of the first signatures to be identified for the possibility of crustal protoliths was from studies of the carbon isotopes of the diamonds (e.g., Soblev et al, 1979; Deines et al., 1984, 1987, 1989, et cetera; Javoy et al., 1986; Kirkley et al, 1991; Nisbet et al., 1994), as shown in Figure 1. It is abundantly clear from the $\delta^{13} \mathrm{C}$ values that the eclogitic diamonds possessed such a wide spread $(+1$ to -35 $\%$ ) as to have involved processes extraneous to the mantle i.e., crustal modifications, possibly by biogenic mechanisms. But, suggestions of crustal origins for the carbon went largely unrecognized until a second major signature was brought to bear on the eclogite subject - i.e., oxygen isotopes. It was probably the study of Garlick et al. (1971), as part of the initial study of Roberts Victor by MacGregor and Carter (1970), which first brought the non-mantle $\delta^{18} \mathrm{O}$
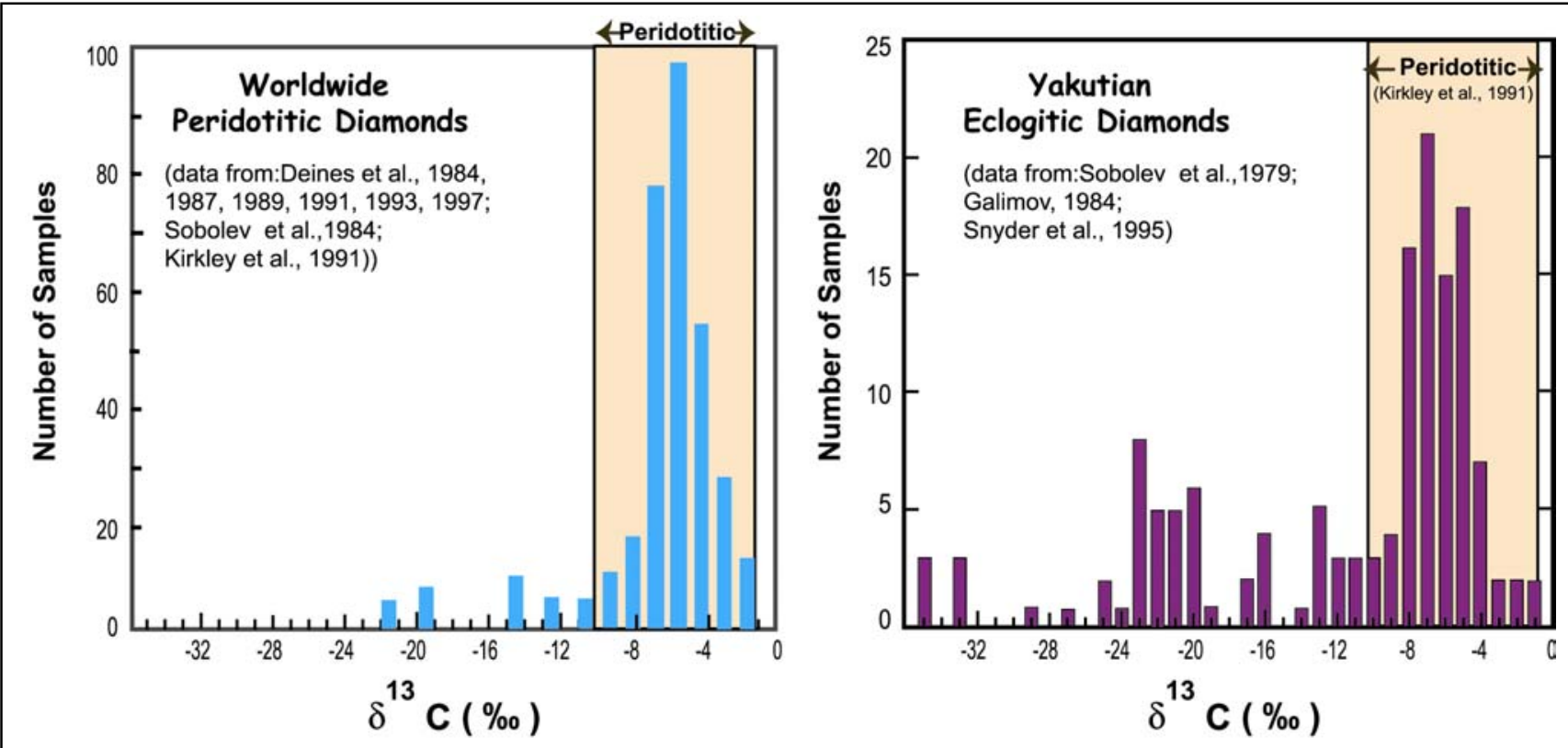

Figure 1. Carbon isotope values for both P-type (peridotitic) and E-type (eclogitic) diamonds. 
values from eclogites to the attention of the world, but without an adequate explanation. Subsequently, it was the oxygen isotope studies by Gregory and Taylor (1981) that laid the groundwork for understanding the $\delta^{18} \mathrm{O}$ values of oceanic crust, which were both above and below the accepted mantle value (now, $5.4 \pm 0.4 \%$, Mattey et al., 1994), as shown by the example in Figure 2.

With a decade-plus hiatus, it was not until the classic work of MacGregor and Manton (1986) that real doubt was manifest in the minds of the mantle-eclogite petrologists. Literally dozens of subsequent studies have confirmed the scenario of subduction of ancient oceanic crust as the tectonic mechanism for bringing the crustal protoliths down into the mantle, into the P-T regime for diamond formation. Among these studies by our group are: Shervais et al. (1988); Taylor and Neal (1989); Neal et al. (1990); Jerde et al. (1993); Taylor (1993); Taylor et al. (1996, 1998, 2000, 2002, 2003a,b); Sobolev et al. (1994); Snyder et al. (1995, 1997), Beard et al. (1996); Sobolev et al. (1998), et cetera. These subsequent studies of diamondiferous eclogites, particularly from Yakutia, have revealed several additional crustal signatures, such as +Eu anomalies in garnet and omphacite, both in diamond inclusions and in the host eclogites; $\varepsilon N d$ values to +250 ; decoupled $\mathrm{Rb}-\mathrm{Sr}$ and $\mathrm{Sm}-\mathrm{Nd}$; unusually high ${ }^{87} \mathrm{Sr} /{ }^{86} \mathrm{Sr}$; et cetera.

The mantle-eclogite, crustal-protolith hypothesis (e.g., Beard et al., 1996) is envisioned as the subduction of an ophiolite sequence beneath a continental craton, whereby the basaltic and mafic components were metamorphosed, devolatilized and partially melted, and otherwise transformed into eclogites. This tectonic scheme has found support from the studies of Ireland et al. (1994) and Rudnick et al. (1995) with the formation of the TTG igneous complex. Being within the diamond-stability field, the eclogites have later experienced metasomatic diamond formation. With this scenario for crustal protoliths for eclogies, it is surprisingly to us, that the closely associated diamondiferous peridotites are considered to be of original mantle origin. We pose the query: Could the ultramafic portion of the subducted crust account for at least some of the mantle peridotites? This is the subject of the present study, and we will take a similar approach that history has shown to have worked for the eclogites.

\section{OPHIOLITES}

It is generally accepted that the ancient oceanic crust is effectively represented by an ophiolite complex (Coleman, 1977). The term "ophiolite" refers to an assemblage of mafic to ultramafic rocks in the following sequence (from bottom up): Ultramafic Complex, consisting of variable proportions of harzburgite, lherzolite, and dunite, with metamorphic overprint; Ultramafic-Mafic Gabbroic Complex, containing cumulate peridotites and pyroxenites, leading upward into gabbroic varieties; Mafic Sheeted-Dike Complex; Mafic Volcanic Complex, consisting of pillow basalts with sodic felsic intrusives and extrusives, and an overlying sedimentary section with cherts, shales, and limestones (Coleman, 1977). The Ultramafic Complex contains some inter-cumulate plagioclase in the peridotites, and crystal fractionation from the melt produces peridotites interlayered with plagioclase-rich gabbros, troctolites, and anorthosites. This is a generalized sequence of rock-type stratigraphy, and each ophiolite complex has its own variations on this central theme (Fig. 3). The important point is Ophiolites are oceanic crust developed at a spreading oceanic ridge, and are representative of oceanic crust.

Probably the two most studied ophiolite occurrences are the Troodos Ophiolite, Cyprus, and the Semail Ophiolite, Oman (Fig. 3). In a classic study of this latter
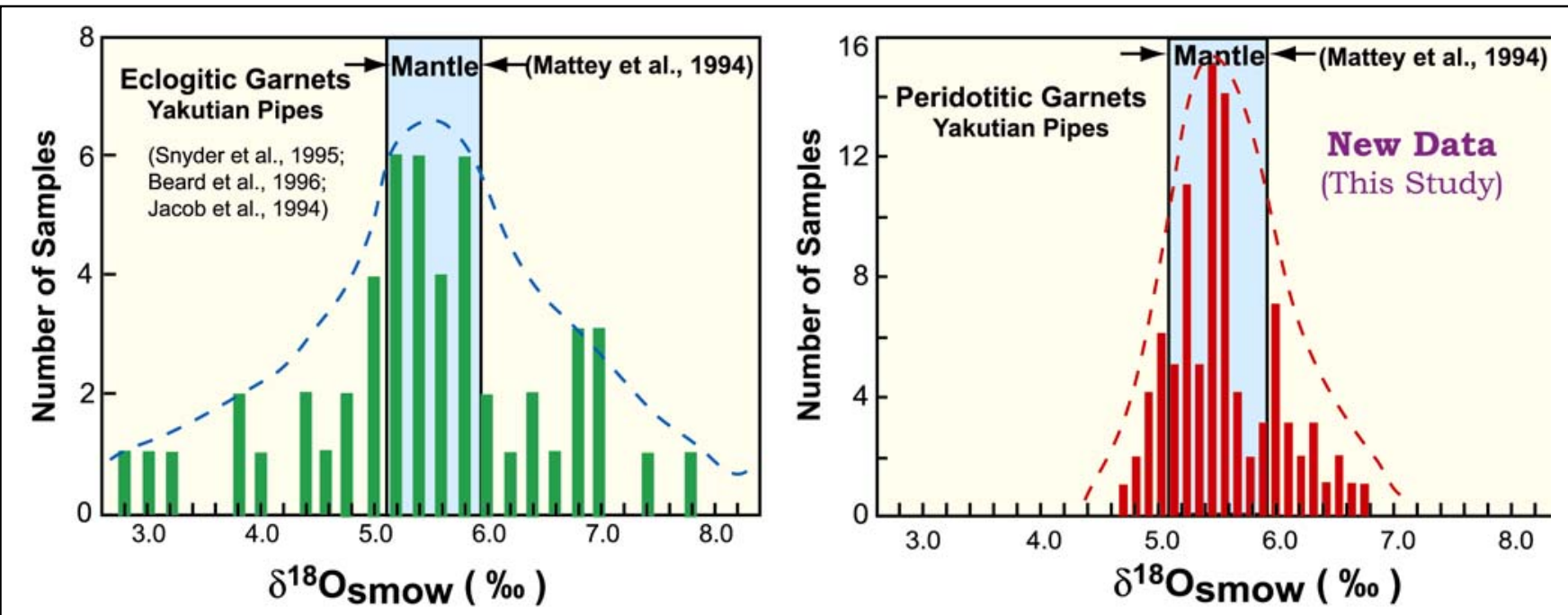

Figure 2. Oxygen isotope values for eclogitic and peridotitic garnets from Yakutian kimberlite pipes. 


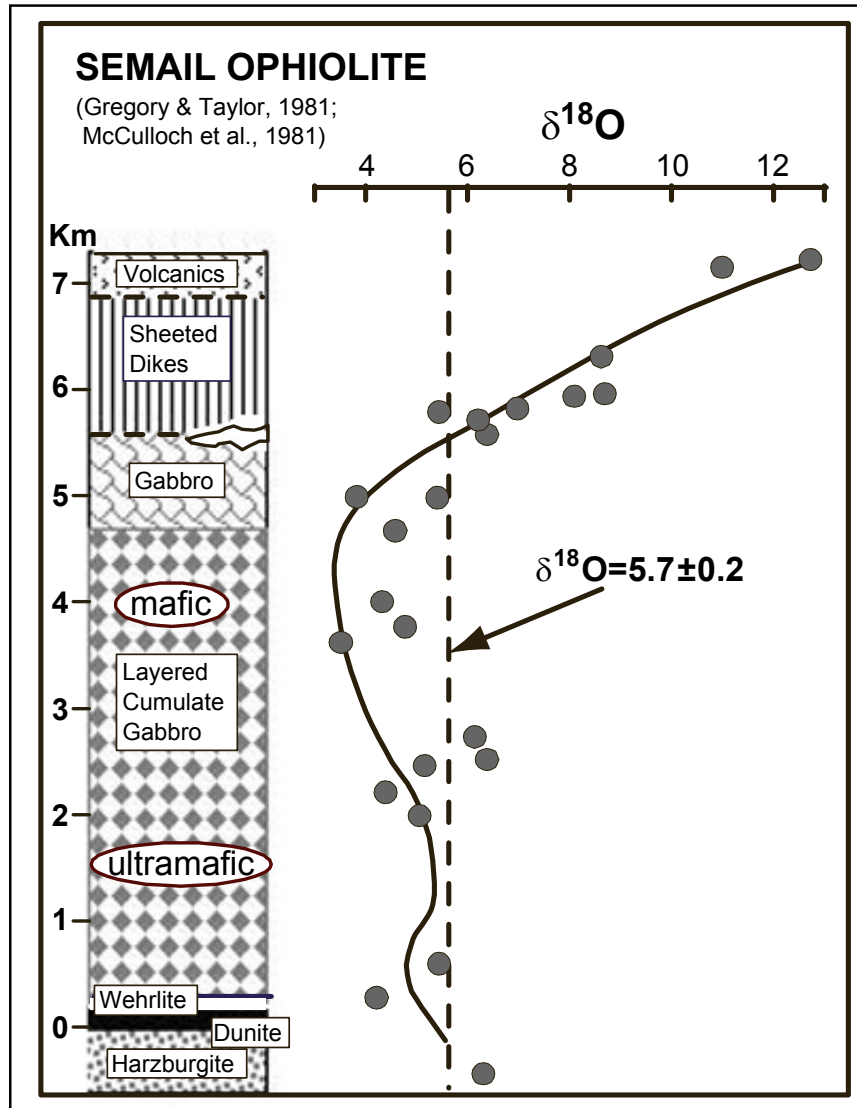

Figure 3. Cross-section of the Semail Ophiolite Complex, Oman, showing the variations in $\delta^{18} \mathrm{O}$ values as a function of position within the complex. The higher than mantle values near the top are due to low-temperature hydrothermal alteration by seawater, whereas the less-than-mantle values are due to high-temperature alteration (Gregory and Taylor, 1981).

complex, Gregory and Taylor (1981) demonstrated that this ancient oceanic lithosphere provides a framework for the time-averaged effects of seawater circulation in "fossil" hydrothermal systems associated with spreading centers. The bottom portion of the Semail complex includes tectonized harzburgitic peridotite; a basal zone of Ol-Cpx cumulates (wehrlites); followed by $3-5 \mathrm{~km}$ of ultramafic to mafic cumulate gabbros, grading into a km-thick zone of Plg-Hrbl-Cpx-Ol-Mt non-cumulate gabbro; with an abrupt transition interval of gabbro, with $10 \%$ diabase dikes; to a 1$2 \mathrm{~km}$ sheeted-dike complex, topped by pillow lavas, interbedded with cherty sediments (Fig. 3). The study of McCulloch et al. (1981) further approached the Rb-Sr and $\mathrm{Sm}-\mathrm{Nd}$ systematics as these related to the fluid-flow of the hydrothermal modifications to the oxygen isotopic values.

Gregory and Taylor (1981) demonstrated that the lowtemperature hydrothermal alteration of seawater, in the upper portions of the ophiolite, effectively raised the $\delta^{18} \mathrm{O}$ above the average MORB value of $5.7 \pm 0.2 \%$ (later modified to $5.5 \pm 0.4 \%$; Mattey et al., 1994), as shown in Figure
3. High-temperature alteration in the lower portions of the complex effectively reduces the $\delta^{18} \mathrm{O}$ values. It is envisioned that most mantle eclogites come from the upper $2 / 3$ rds of the ophiolite complexes (= mostly mafic). It is to the lower $1 / 3$ rds portion of the oceanic crust, with its ultramafic to mafic compositions, that we address this study, first from the carbon isotopic compositions of the peridotitic (ultramafic) diamonds; then, from the oxygen values of the mantle peridotites.

\section{MANTLE PERIDOTITES}

It has been generally agreed that mantle peridotites occurring as xenoliths in kimberlites are representative of the cratonic mantle (Boyd and Finnerty, 1980; Boyd et al., 1997). However, below we address not the mineralogy or whole-rock chemistry of the peridotites, but the stable isotopes of the peridotitic minerals and P-type diamonds.

\section{CARBON ISOTOPES}

The restricted $\delta^{13} \mathrm{C}$ values for P-type (peridotitic) diamonds is commonly used as evidence for the mantle origin of peridotites, as depicted in Figure 1. However, a compilation of $\delta^{13} \mathrm{C}$ data, published largely by Peter Deines and colleagues (see numerous references) for P-type diamonds, mainly from several South African pipes, shows a significant number of values that are significantly more depleted in ${ }^{13} \mathrm{C}$ than the mantle field (to-21\%o). The major compilation of carbon isotopes of diamonds by Kirkley et al. (1991) also showed several $\delta^{13} \mathrm{C}$ values that were outside the mantle range of -1 to $-10 \%$.

As can be readily seen in Figure 1 , the $\delta^{13} \mathrm{C}$ values for eclogitic diamonds are predominantly within the mantle region, but almost $1 / 3^{\text {rd }}$ of the data are definitely lighter in carbon. In contrast, the $\delta^{13} \mathrm{C}$ values for mantle peridotitic diamonds are fully $90 \%$ in the mantle range. But, it has been these few lighter carbon values that have provided the important impetus to consider the ultimate source of the peridotites.

\section{OXYGEN ISOTOPES}

Since the advent of the laser-fluorination technique for oxygen-isotope analysis, several elegant and extensive studies have been performed on mantle-peridotite minerals (e.g., Mattey et al., 1994). Such studies have greatly broadened our knowledge of the range of $\delta^{18} \mathrm{O}$ values. Indeed, some mantle peridotites are enriched in ${ }^{18} \mathrm{O}$, with olivine possessing $\delta^{18} \mathrm{O}$ values extending from $+4.5 \%$ to $+7.2 \%$ (Mattey et al., 1994). In a remarkably delicate and exacting study of diamond inclusions by the laser-fluorination technique, Lowry et al. (1999) determined that chrome pyrope DIs have a range of $\delta^{18} \mathrm{O}$ from $+4.6 \%$ to $+5.6 \%$. The possibility is intriguing of "outliers" to the normal mantle value of $+5.5 \pm 0.4 \%$ being from a non-mantle oxygen source, just like the case was for the few $\delta^{13} \mathrm{C}$ values that fell 'outside 
the box.' With this in mind, we have determined the oxygen isotopes in a large population of peridotitic garnets from the archives of the ALROSA Co. in Mirny, Yakutia.

\section{$\delta^{18} \mathrm{O}$ in MANTLE PERIDOTITE GARNETS}

Fresh garnets were carefully selected from over a hundred peridotites collected from several Yakutian kimberlites, many diamondiferous. The garnets were crushed and sieved to $100 \mu \mathrm{m}$ and picked using a binoc microscope. After a second crushing and picking of the first selection, the clean, optically gem-quality garnet grains were washed with water and acetone. A split of each sample was used for EMP analyses. Another $10 \mathrm{mg}$ portion was set aside for oxygenisotope analyses by laser-fluorination at the University of Wisconsin. The oxygen-isotope analyses were performed on the garnet mineral separates, approximately 1-2 mg per run, using a $32 \mathrm{~W} \mathrm{CO}_{2}$ laser, $\mathrm{BF}_{5}$, and a dual-inlet Finnigan MAT 251 mass spectrometer. Replicate analyses were performed on many samples, particularly those that had initial oxygen values outside that of mantle. The general procedures are those discussed by Spicuzza et al. (1998). All values are reported with respect to V-SMOW.

The majority of the $\delta^{18} \mathrm{O}$ garnet values (Fig. 2) plot within the accepted mantle range of $5.5 \pm 0.4 \%$ (Mattey et al., 1994). However, a significant number $(\sim 20 \%)$ plot outside this window, both above and below. These values are interpreted to represent the effects of both high- and lowtemperature hydrothermal alterations that occurred in the oceanic crust prior to subduction of this slab into the mantle.

\section{CONCLUSIONS}

We have demonstrated that there are $\delta^{18} \mathrm{O}$ values for mantle peridotitic garnets that are outside the accepted mantle range - i.e., signatures of crustal origin - similar to that shown by $\delta^{13} \mathrm{C}$ data. We propose that at least some of the diamondiferous peridotites, as well as mineral inclusions in P-type diamonds, owe their ultimate heritage to subducted oceanic crust, possibly represented by the lower portion of an ophiolite complex. Additional compositional and isotopic data are under examination to further bolster or negate this paradigm. The defining data set has yet to be collected.

\section{REFERENCES}

Beard, B., Fraracci, K.N., Taylor, L.A., Snyder, G.A., Clayton, R.N., Mayeda, T.K., Sobolev, N.V., 1996. Petrography and geochemistry of eclogites from the Mir kimberlite, Yakutia, Russia. Contrib. Mineral. Petrol. 125, 293-310.

Boyd, F. R., Finnerty, A. A., 1980. Conditions of origin of natural diamonds of peridotitic affinity: Jour. Geophys. Res., v. 85, p. 6911-6918.

Boyd, F.R., Pokhilenko, N.P., Pearson, D.G., Mertzman, S.A., Sobolev, N.V., Finger, L.W., 1997. Composition of the Siberian cratonic mantle: evidence from Udachnaya per- idotite xenoliths: Contrib. Mineral. Petrol., v. 128, p. 228-246

Coleman, R.G., 1977. Ophiolites: Ancient Oceanic Lithosphere? Springer-Verlag, Berlin, $229 \mathrm{p}$.

Deines, P., 2002. The carbon isotope geochemistry of mantle xenaliths. Earth-Sciences Reviews 58, 247-278.

Deines, P., Harris, J. W., 1995. Sulfide inclusion chemistry and carbon isotopes of African diamonds: Geochimica et Cosmochimica Acta, v. 59, p. 3173-3188.

Deines, P., Gurney, J.J., Harris, J.W., 1984. Associated chemical and carbon isotopic composition variations in diamonds from Finch and Premier kimberlite, South Africa. Gechim. Cosmochim. Acta 48, 325-342.

Deines, P., Harris, J.W. Gurney, J.J., 1987. Carbon isotopic composition, nitrogen content and inclusion composition of diamonds from the Roberts Victor kimberlite, South Africa: Evidence for ${ }^{13} \mathrm{C}$ deposition in the mantle. Geochim. Cosmochim. Acta 51, 1227-1243.

Deines, P., Harris, J.W., Spear, P.M., Gurney, J.J., 1989. Nitrogen and ${ }^{13} \mathrm{C}$ content of Finch and Premier diamonds and their implications. Geochim. Cosmochim. Acta 53, 13671378.

Deines, P., Harris, J.W., Robinson, D.N., Gurney, J.J., Shee, S.R., 1991a. Carbon and oxygen isotope variations in diamond and graphite eclogites from Orapa, Botswana, and the nitrogen content of their diamonds. Geochim. Cosmochim. Acta 55, 515-524.

Deines, P., Harris, J.W., Gurney, J.J., 1991b. The carbon isotopic composition and nitrogen content of lithosphere and asthenospheric diamonds from the Jagersfontein and Koffiefontein kimberlite, South Africa. Geochim. Cosmochim. Acta 55, 2615-2625.

Deines, P., Harris, J.W., Gurney, J.J., 1993. Depth-related carbon isotope and nitrogen concentration variability in the mantle below the Orapa kimberlite, Botswana, Africa. Geochim. Cosmochim. Acta 57, 2781-2796.

Deines, P., Harris, J.W., Gurney, J.J., 1993. Depth-related carbon isotope and nitrogen concentration variability in the mantle below the Orapa kimberlite, Botswana, Africa: Geochim. Cosmochim. Acta, v. 57, p. 2781-2796.

Deines, P., Harris, J.W., Gurney, J.J., 1997. Carbon isotope ratios, nitrogen content and aggregation state, and inclusion chemistry of diamonds from Jwaneng, Botswana. Geochim. Cosmochim. Acta 61, 3993-4005.

Galimov, E.M., $1984 \mathrm{a},{ }^{13} \mathrm{C} /{ }^{12} \mathrm{C}$ of diamonds: vertical zonality of diamond formation in the lithosphere. Proc. $27^{\text {th }}$ Int. Geol. Cong. 11, 279-307.

Galimov, E.M., 1884b, The relationship between formation conditions and variations in isotope composition of diamonds. Geokhimiya 8, 1091-1118.

Garlick, G.D., MacGregor, I.D., Vogel, D.E., 1971. Oxygen isotope ratios in eclogites from kimberlites. Science 172, 1025-1027.

Gregory, R.T., and Taylor, Jr., H.P., 1981. An oxygen isotope profile in a section of Cretaceous oceanic crust, Samail ophiolite, Oman: Evidence for $\delta^{18} \mathrm{O}$ buffering of the oceans by deep $(>5 \mathrm{~km})$ seawater-hydrothermal circulation at mid-ocean ridges. Jour. Geophys. Res. 86, 2737 2755.

Ireland, T. R., Rudnick, R. L., Spetsius, Z., 1994. Trace elements in diamond inclusions from eclogites reveal link to Ar- 
chean granites: Earth Planet. Sci. Lett., v. 128, p. 199213.

Jacob, D., Jagoutz, E., Lowry, D. Mattey, D, Kudrjavtseva, G., 1994. Diamondiferous eclogites from Siberia: Remanents of Archean oceanic crust. Geochim. Cosmochim. Acta 58, 5191-5207.

Javoy, M., Pineau, F., Delorme, H., 1986. Carbon and nitrogen isotopes in the mantle: Chem. Geol., v. 57, p. 41-62.

Jerde, E.A., Taylor, L.A., Crozaz, G., Sobolev, N.V., Sobolev, V.N., 1993. Diamondiferous eclogites from Yakutia Siberia: Evidence for a diversity of protoliths. Contributions to Mineralogy and Petrology 114, 189-202.

Kesson, S.E., Ringwood, A.E., 1989. Slab-mantle interactions: 2. The formation of diamonds: Chem. Geol., v. 78, p. 97118.

Kirkley, M.B., Gurney, J.J., Otter, M.L., Hill, S.J., Daniels, L.R., 1991. The application of $C$ isotope measurements to the identification of the sources of $\mathrm{C}$ in diamonds: a review. Applied Geochem. 6, 477-494.

Lowry, D., Mattey, D.P., Harris, J.W., 1999. Oxygen isotope composition of syngenetic inclusions in diamond from the Finch Mine, RSA. Geochim. Cosmochim. Acta 63, 1825-1836.

MacGregor, I.D., Carter, J.L., 1970. The chemistry of clinopyroxene and garnets of eclogite and peridotite xenoliths from the Roberts Victor mine, South Africa. Phys. Earth Planet. Inter. 3, 391-397.

MacGregor, I.D., Manton, W.I., 1986. Roberts Victor eclogites: Ancient oceanic crust. Jour. Geophys. Res. 91, 14,06314,079.

Mattey, D., Lowry, D., Macpherson, C., 1994. Oxygen isotope composition of mantle peridotite. Earth Planet. Sci. Lett. $128,231-241$.

McCulloch, M.T., Gregory, R.T., Wasserburg, G.J., Taylor, Jr., H.P., 1981. Sm-Nd, Rb-Sr, and ${ }^{18} \mathrm{O} /{ }^{16} \mathrm{O}$ isotopic systematics in an oceanic crustal section: Evidence from the Samail ophiolite. Jour. Geophys. Res. 86, 2721-2735.

Meyer, H.O.A., 1987. Inclusions in diamonds: In Nixon, P. H. (Ed.), Mantle Xenoliths, Wiley, Chichester, p. 501-523.

Neal, C.R., Taylor, L.A., Davidson, J.P., Holden, P., Halliday, A.N., Paces, J.B., Clayton, R.N., Mayeda, T.K., 1990. Eclogites with oceanic crustal and mantle signatures from the Bellsbank kimberlite, South Africa, Part 2: Sr, $\mathrm{Nd}$, and $\mathrm{O}$ isotope chemistry. Earth Planet. Sci. Lett. 99, 362-379.

Nisbet, DE.G., Mattey, D.P., Lowry, D., 1994. Can diamonds be dead bacteria?: Nature, v. 367, p. 694.Shulze, D.J., J.R. Valley, D.R. Bell, and M.J. Spicuzza, 2001, Oxygen isotope variations in $\mathrm{Cr}$-poor megacrysts from kimberlite. Geochim. Cosmochim. Acta 65, 4375-4384.j

Rudnick, R.L., Jackson, I.N.S., 1995. Nature and composition of the continental crust: a lower crustal perspective. Rev. Geophys. 33, 267-309.

Shervais, J.W., Taylor, L.A., Lugmair, G.W., Clayton, R.N., Mayeda, T.K., Korotev, R.L., 1988. Early proterozoic oceanic crust and the evolution of subcontinental mantle: Eclogites and related rocks from southern Africa. Geol. Soc. Amer. Bull. 100, 411-423.

Snyder, G.A., Taylor, L.A., Jerde, E.A., Clayton, R.N., Mayeda, T.K., Deines, P., Rossman, G.R., Sobolev, N.V., 1995. Archean mantle heterogeneity and the origin of diamondiferous eclogites, Siberia: Evidnece from stable iso- topes and hydroxly in garnet: Amer. Mineral., v. 80, p. 799-809.

Snyder, G.A., Taylor, L.A., Crozaz, G., Halliday, A.N., Beard, B.L., Sobolev, V.N., Sobolev, N.V., 1997. The origins of Yakutian eclogite xenoliths: Jour. Petrol., v. 38, p. 85-113

Sobolev, N.V., 1977, Deep-Seated Inclusions in Kimberlites and the Problem of the Composition of the Upper Mantle. Publ. Amer. Geophys. Union, Wash., DC, 279 pp.

Sobolev, N.V., Galimov, E.M., Ivanovskaya, I.N., Yefimova, E.S., 1979. Carbon isotope composition of diamonds containing crystalline inclusions. Doak. Akad. Nauk. SSSR 249, 1217-1220.

Sobolev, N. V., Taylor, L. A., Zuev, V.M., Bezborodov, S.M., Snyder, G.A., Sobolev, V.N., Yefimova, E. S., 1998. The specific features of eclogitic paragenesis of diamonds from Mir and Udachnaya kimberlite pipes (Yakutia): Russian Geol. Geophys., Geologiya I Geofizika, v. 39, no. 12 , p. $1667-1678$.

Sobolev, V.N., Taylor, L.A., Snyder, G.A., Sobolev, N.V., 1994. Diamondiferous eclogites from the Udachnaya kimberlite pipe, Yakutia: Int'l. Geol. Rev., v. 36, p. 42-64

Spicuzza, M.J., Valley, J.W., Kohn, M.J., Girand, J.P., and Fouillac, A.M., 1998. The rapid heating, defocused beam technique: $\mathrm{A} \mathrm{CO}_{2}$-laser-based method for highly precise and accurate determination of $\delta^{18} \mathrm{O}$ values of quartz. Chem. Geol. 144, 195-203.

Taylor, L.A., 1993. Evolution of the subcontinental mantle beneath the Kaapvaal craton: a review of evidence for crustal subduction for Bellsbank eclogites: Russian Geol. Geophys., Geologiya Geofizika, v. 34, n. 12, p. 21-39.

Taylor, L.A., Neal, C.R., 1989. Eclogites with oceanic crustal and mantle signatures from the Bellsbank kimberlite, South Africa, Part I: Mineralogy, petrography, and whole rock chemistry: Jour. Geol., v. 97, p. 551-567

Taylor, L.A., Snyder, G.A., Crozaz, G., Sobolev, V.N., Sobolev, N. V., 1996. Eclogitic inclusions in diamonds: Evidence of complex mantle processes over time: Earth Planet. Sci. Lett., v. 142, p. 535-551.

Taylor, L. A., Milledge, H. J., Bulanova, G. P., Snyder, G. A., and Keller, R. A., 1998, Metasomatic eclogitic diamond growth: evidence from multiple diamond inclusions: Int'1. Geol. Rev., v. 40, p. 592-604.

Taylor, L.A., Snyder, Keller, R., Rremley, D.A., Anand, M., Wiesli, R.W., Valley, Kurosawa, M., Sobolev, N. V., 2003. Petrogenesis of group A eclogites and websterites: Evidence from the Obnazhennaya kimberlite, Yakutia, Contr. Mineral. Petro., in press.

Taylor, L. A., Anand, M., Promprated, P., Floss, C., Sobolev, N. V., 2003. Non-syngenetic (protogenetic) mineral inclusions in large diamonds from Yakutia, Amer. Mineral., in press.

Contact: L.A. Taylor, Planetary Geosciences Institute, Department of Geological Sciences, University of Tennessee, Knoxville, TN 37996,E-mail:lataylor@utk.edu 